DOI 10.31392/NPU-nc.series 2.2019.21(28).20

УДК: 37.09:004.73

В.П. Вембер

кандидат педагогічних наук, доцент;

Д.Л. Настас

науковий співробітник НДЛ інформатизації освіти

Київського університету імені Бориса Грінченка

\title{
ВИКОРИСТАННЯ ХМАРНИХ СЕРВІСІВ ДЛЯ ПІРІНГОВОЇ ВЗАЕМОДІЇ У НАВЧАЛЬНОМУ ПРОЦЕСІ
}

Анотація. У статті розглядаються проблеми модернізації освіти, зокрема особливості впровадження пірінгової взаємодії в навчальному процесі закладів освіти. Розглянуто приклади діючих систем пірінгової взаємодії за кордоном та в Україні. Подано особливості пірінгового оцінювання та поради щодо розробки критеріїв оцінювання. Визначено хмарні сервіси, які можуть використовуватися для реалізації пірінгової взаємодії та пірінгового оцінювання, зокрема окремі pecyрси в LMS Moodle, дослідницькі навчальні простори, додатки Google, такі як Google Таблиці, Google Форми, Google Документи, блоги, а також віртуальні дошки, та розглянуто особливості іх використання.

Ключові слова: «peer-to-peer», пірінгова взаємодія, пірінгове оцінювання, хмарні сервіси.

У XXI столітті неможливо модернізувати освітній процес без врахування тенденційних змін, які орієнтовані на світові стандарти. Все частіше можна побачити, що освітні реформи виходять за межі однієї держави, вони набувають інтернаціонального характеру. Акценти зміщуються в сторону розвитку особистості, впроваджуються новітні технології, що неодмінно призводить до потреби переосмислювати та вдосконалювати педагогічні методи. Українська освіта повинно відповідати міжнародним стандартам, тому перебуває у процесі перебудови, трансформується, шукаються нові методи та технології, відбувається адаптація до вимог сучасності. Студент закладу вищої освіти потребує особистісного підходу; відкритості ресурсів для навчання та самопізнання; переходу від переважно інформативних форм до методів і форм активного навчання 3 використанням елементів проблемності, наукового пошуку тощо; переходу від суворо регламентованих контрольованих способів організації педагогічного процесу до розвивальних, активізуючих; перетворення позиції педагога і позиції студента в особистісно-рівноправні, в позиції людей-співробітників.

Для забезпечення якісного освітнього процесу все частіше необхідно шукати різноманітні інструменти, через використання яких забезпечується самостійна, дослідницька та самоорганізаційна діяльність студентів. 3 впровадженням змішаного, дистанційного навчання, появою великої кількості масових відкритих онлайн курсів все більшого поширення набуває технологія пірінгового навчання (peer learning). Складовою пірінгового навчання $є$ пірінгове оцінювання (peer assessment), що дозволяє вийти за рамки стандартних форм діагностики навчальних досягнень викладачем, надає можливість студенту оцінити роботи своїх однолітків, виявити стандартні помилки у виконанні та переосмислити завдання.

Метою статті є визначення особливостей використання хмарних сервісів для впровадження пірінгової взаємодії в освітній процес закладів вищої освіти.

Термін «peer-to-peer» був вперше використаний у 1984 році Парбауелом Йонугуйтсманом (Parbawell Yohnuhuitsman) під час розробки архітектури Advanced Peer to Peer Networking фірми IBM. Цей термін використовувався для пояснення функціонування комп'ютерної мережі, принцип використання якої засновано на рівноправності учасників і характеризуються тим, що ії елементи можна зв'язувати між собою, на відміну від традиційної архітектури, коли лише окрема категорія учасників може надавати певні сервіси іншим. Отже, коли термін «peer-to-peer» почали використовувати в освіті, то його основна ідея залишилась, студенти стали рівноправними учасниками освітнього процесу, вони можуть спільно створювати навчальний контент, обговорювати в групах проблемні моменти, здійснювати оцінювання інших учасників, використовувати відгуки для вдосконалення своїх знань та навичок. Під час пірінгового навчання викладачі не відмовляються від зобов'язань перед студентами в процесі навчання та оцінювання, а працюють зі студентами, щоб допомогти їм розробляти стратегії навчання та оцінювання, здійснюють всебічну підтримку, виступають у ролі наставника, тьютора.

Специфіка пірінгового навчання, пірінгової взаємодії з використанням IКТ полягає в тому, що воно народилося саме $з$ тих можливостей, яких раніше не було. Його основа - це Інтернет, технології Веб 3.0, масове оцифрування різних матеріалів і велика кількість відкритих освітніх ресурсів (ореп 
educational resources, OER). Прикладом успішно функціонуючої системи пірінгової взаємодії за кордоном може виступати Peer 2 Peer University (P2PU) [2], який діє за підтримки Чиказької публічної бібліотеки і спрямований на оптимізацію взаємодії в професійній педагогічній галузі. Іншим прикладом можуть слугувати масові відкриті онлайн-курси (МВОК), основна ідея яких полягає в наданні слухачам необмеженого часом чи територією доступу до різноманітних навчальних ресурсів. Пірінгова взаємодія у МВОК зазвичай реалізується через можливість використання форумів для користувачів, які допомагають створювати і підтримувати спільноти студентів, викладачів $\mathrm{i}$ асистентів із залученням провідного міжнародного досвіду. До найпопулярніших МВОК можна віднести такі як:

- Coursera (Стенфордский університет);

- MIT Open CourseWare (Массачусетський технологічний інститут);

- EdX (Массачусетський технологічний інститут та Гарвардський університет);

- Prometheus (ЗВО України) тощо.

Засобом для налагодження пірінгової взаємодії можуть також слугувати тематичні блоги. В статті «Blogging as an Innovative Method of Peer-to-Peer Educational Sharing» [3] автори вказують на ефективність ведення блогів у сфері професійної медичної освіти для систематичного підвищення кваліфікації медичного персоналу. В дослідженнях, які було проведено, зафіксовано підвищення зацікавленості до навчального матеріалу, оскільки ті, хто навчається, міг у вільній формі подати матеріал або створювати форуми для обговорення, також відчувалась підтримка проектів та зацікавленість у публікаціях серед своїх колег. Дружня та професійна атмосфера, зручний доступ до ресурсів та взаємодопомога сприяють розвитку не тільки професійних якостей, а й вмінню співпрацювати, толерантно ставитись до іншої думки та оперативно реагувати на навчальні виклики.

Оскільки українська молодь, як і їх однолітки в світі, переважну більшість часу проводить 3 використанням різноманітних комп'ютерних пристроїв та цілодобовим доступом до мережі Інтернет, було проаналізовано хмарні сервіси, за допомогою яких можна реалізувати пірінгове навчання, та визначено шляхи впровадження пірінгової взаємодії з їх використанням:

1. Використання форумів, чатів, зокрема в LMS Moodle.

2. Автоматизація пірінгового оцінювання за допомогою ресурсу Семінар (Workshop) в LMS Moodle.

3. Використання додатків для пірінгового оцінювання в дослідницьких навчальних просторах (Inquiry Learining Spaces - ILS), розроблених в середовищі Graasp.

4. Групова взаємодія з використанням віртуальних дошок.

5. Ведення спільного блогу.

6. Використання додатків Google.

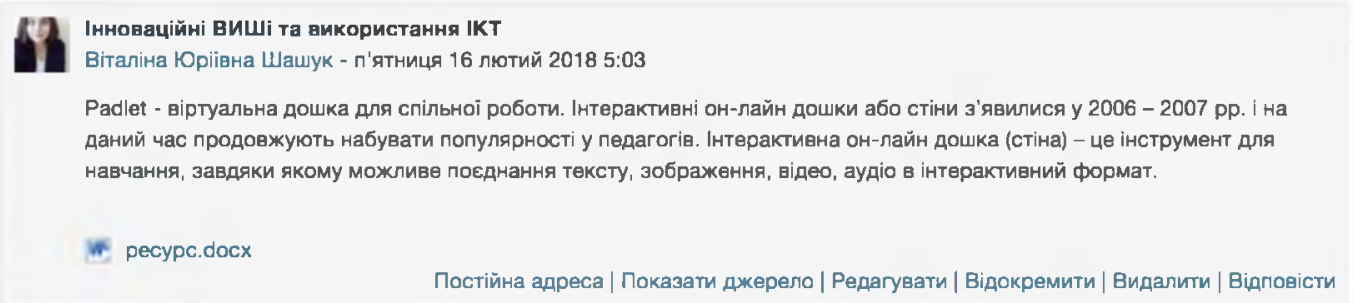

Лілія Русланівна Максимович - п'ятниця 16 лютий 2018 5:07

І справді ресурс корисний для спільної роботи.Дякую!

Постійна адреса | Показати джерело | Редагувати | Відокремити | Видалити | Відповісти

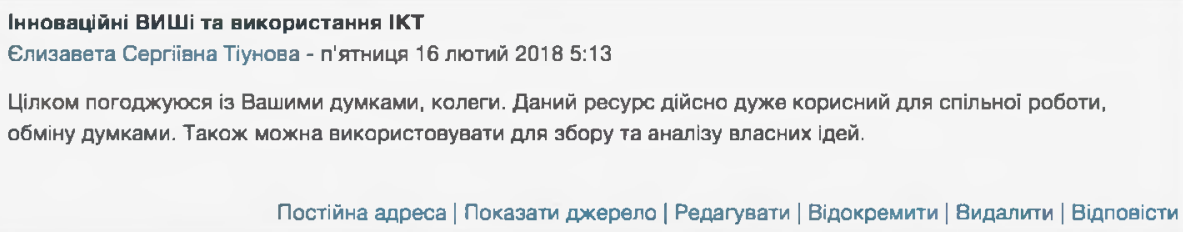

Puc. 1. Використання ресурсу Форум в LMS Moodle

Однією з найпопулярніших систем управління навчанням в Україні $є$ LMS Moodle. На основі низки ресурсів, доступних в цій системі, дозволяє реалізувати пірінгову взаємодію, а саме: Форум 
(Forum), Чат (Chat) та Семінар (Workshop). За допомогою ресурсів Форум та Чат можна забезпечити обмін думками, порадами та корисними відомостями (див. рис. 1). Студенти завдяки цьому інструментарію можуть спілкуватись як в режимі реального часу, так і у режимі відкладеного зв'язку.

Ресурс Семінар (Workshop) використовують для автоматизації пірінгового оцінювання. Під час етапів, передбачених в структурі цього ресурсу, студенти мають різні завдання та заплановано чіткі терміни виконання завдань на кожному етапі. Результати виконання навчальних завдань студенти можуть подати у вигляді будь-якого цифрового контенту (документ, електронна таблиця, презентація тощо), а також можуть додавати текст в поле на сайті, використовуючи вбудований текстовий редактор (посилання на блог, документ, wiki-pecyрс тощо). Після надсилання робіт у систему відбувається перехід до наступного етапу та кожен студент має здійснити оцінювання матеріалів своїх одногрупників (див. рис.2), використовуючи критерії оцінювання, визначені викладачем. Для кращого розуміння, як мають бути оцінені роботи, викладач може надати студентам приклад роботи та приклад ії оцінювання. Студентам надається можливість оцінити одну або кілька робіт. Для забезпечення неупередженого оцінювання всі роботи та студенти, які здійснюють оцінювання, можуть бути в анонімному режимі. На завершальному етапі студенти отримують дві оцінки за семінар: оцінку за свою роботу та оцінку за оцінювання робіт своїх колег. У випадку необ'єктивного оцінювання, якщо оцінка, яку поставив студент, суттєво відрізняється від оцінок інших студентів за дану роботу, оцінка за оцінювання автоматично знижується.

\section{Етап оцінювання}

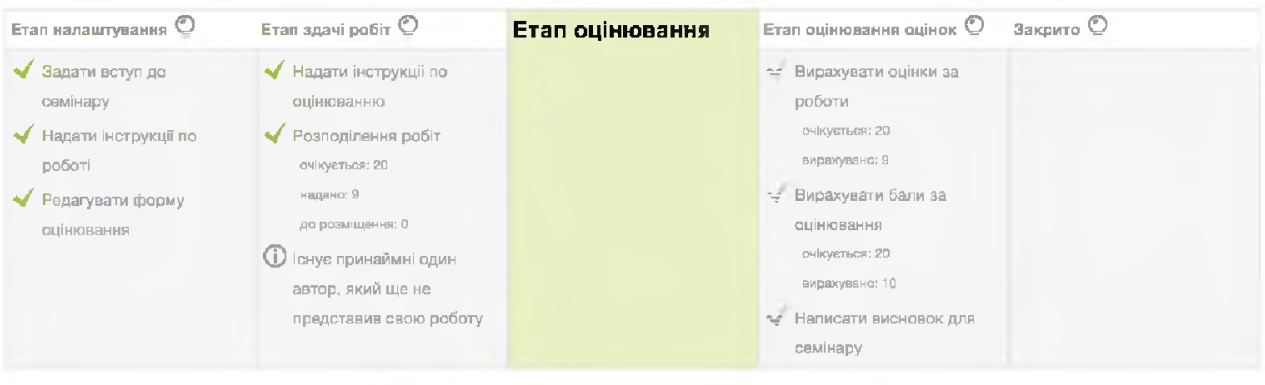

Звіт з оцінювання семінарів $\approx$

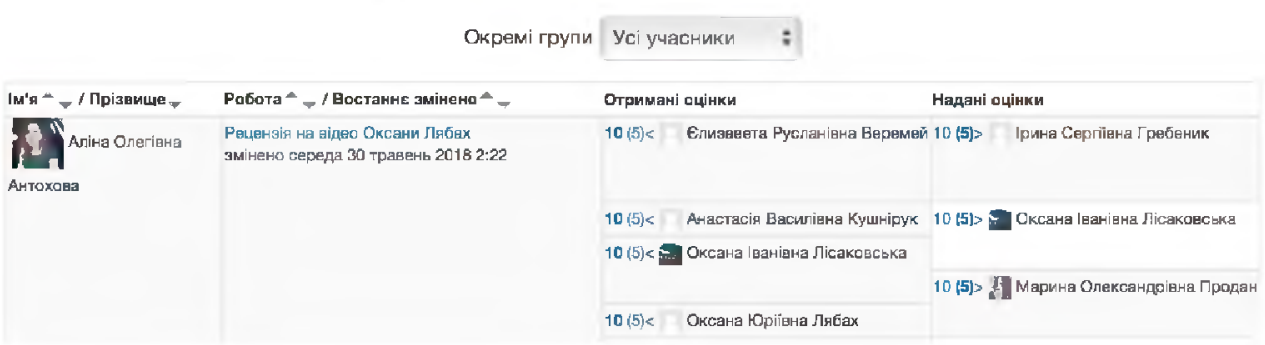

Pис. 2. Використання ресурсу Семінар (Workshop) в LMS Moodle

Важливо враховувати, що під час пірінгової взаємодії студент має не лише доступ до необхідних ресурсів та можливість працювати як одноосібно, так і у групі, а й має чітко усвідомлювати особливості оцінювання. До особливостей пірінгового оцінювання можна віднести: наявність чітких формулювань критеріїв оцінювання, організація роботи студентів в парах чи в групах для оцінювання один одного, застосування принципу подвійної анонімності: студенти не знають, кого оцінюють; студенти не знають, хто їх оцінював. Під час розробки критеріїв оцінювання враховують, що:

- критерії спрямовані на оцінювання роботи студента (на проміжному чи фінальному етапі);

- робота студента оцінюється за критеріями чи порівнюється із запропонованим вчителем зразком, але не з роботами інших студентів;

- критерії мають бути заздалегідь відомими студентам;

- потрібно використовувати чіткий алгоритм виведення оцінки, за яким студент може самостійно визначити свій рівень досягнень і оцінку;

- критерій оцінювання - це конкретний вираз міри досягнення навчальних цілей. Можна оцінювати тільки те, чого навчають [1].

Можливості для пірінгового оцінювання передбачені також в деяких додатках дослідницьких навчальних просторів (Inquiry Learning Spase - ILS), які можуть бути створені з використанням інструментарію платформи Graasp (адреса веб-сайту: http://graasp.eu). Для забезпечення пірінгового оцінювання можна використати, зокрема, додатки Question Scratchpad, Table Tool, Peer Assessment Tool [4]. Використання додатку Table Tool надає можливість додавати таблиці, в яких студенти мають можливість заповнювати порожні клітинки відповідно до завдання. Додаток Question Scratchpad може бути використаний для навчання учнів та студентів формулювати запитання різних 
типів на вказану тему, що надає можливість використовувати під час створення запитання запропонований набір слів або вводити запитання з клавіатури. Під час налаштування цих додатків можна увімкнути режим пірінгового оцінювання та вказати критерії, за якими буде відбуватись оцінювання. Учні в режимі роботи з ILS після виконання завдання обирають інструмент ¿ , щоб попросити відгук на свою роботу (див. рис. 3).

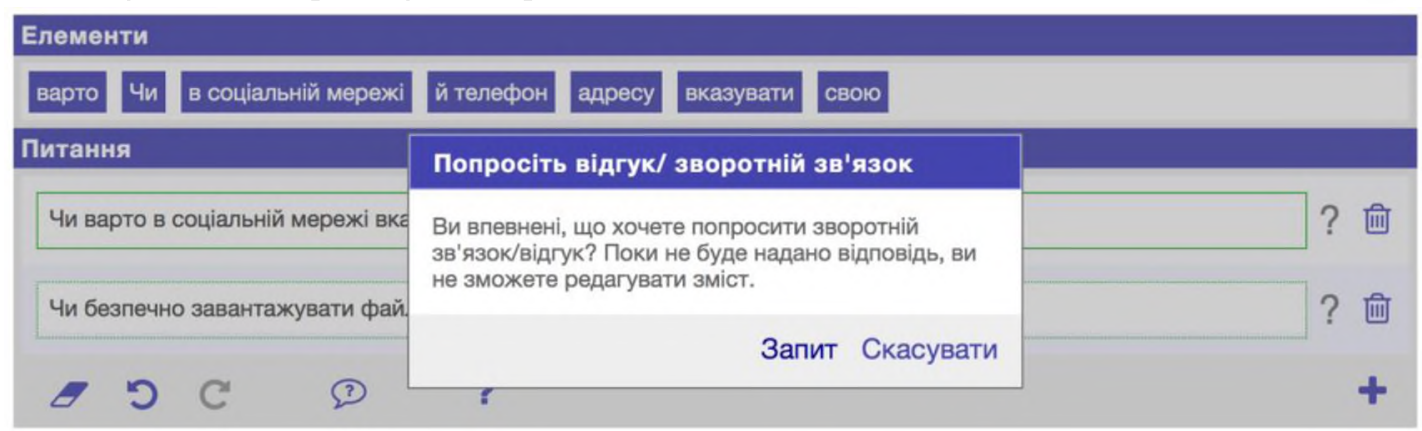

Puс. 3. Використання додатку Question Scratchpad для пірінгового оиінювання

Для того, щоб повною мірою використати можливості пірінгового оцінювання за допомогою додатках Table Tool та Question Scratchpad, викладач має використати також додатків Peer Assessment Tool, який зазвичай додають в розділ Teacher Dashboard, доступний лише для вчителя. За допомогою цього додатка після отримання запитів на оцінювання вчитель призначає, хто з студентів має оцінити роботи інших (див. рис.4). Один студент може оцінювати роботи кількох студентів, а також можна вказати, щоб одну роботу оцінювали кілька студентів.

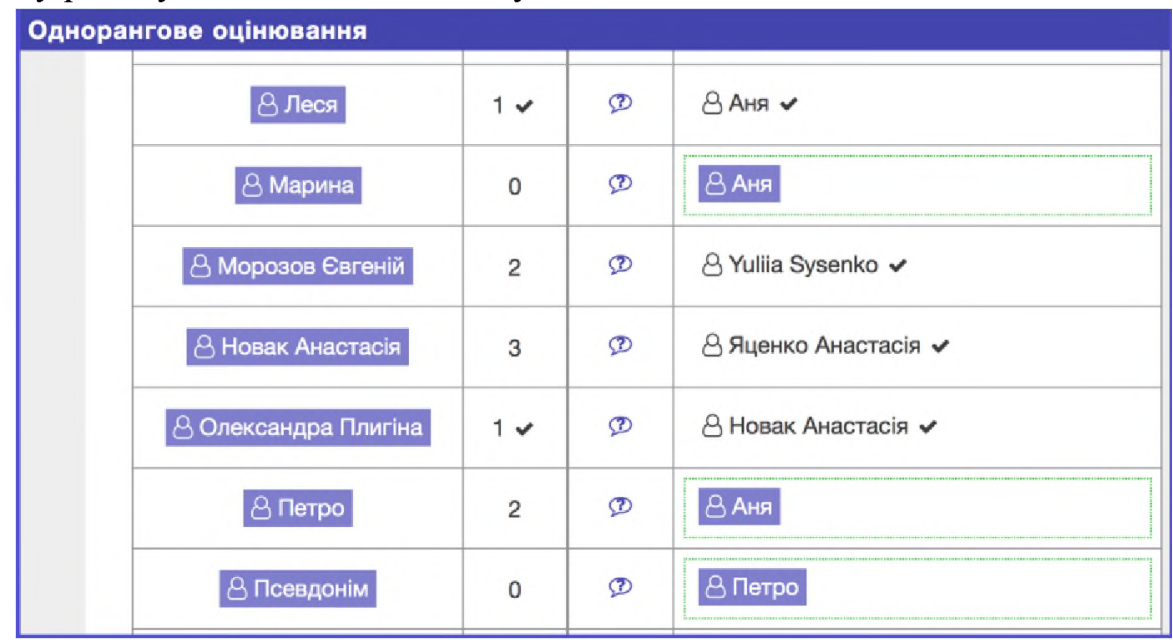

Puс. 4. Bикористання додатку Peer Assessment Tool

Якщо студенту буде призначена робота для оцінювання, в середовищі з являється інструмент

, за допомогою якого надається можливість оцінити роботу студента, якого призначив вчитель, за вказаними критеріями (див. рис. 5). Причому студент не знає, чию роботу він оцінює, та хто оцінює його роботу. Після оцінювання роботи іншим студентом, з'являється інструмент 2 , за допомогою якого студент може переглянути, як була оцінена його робота.

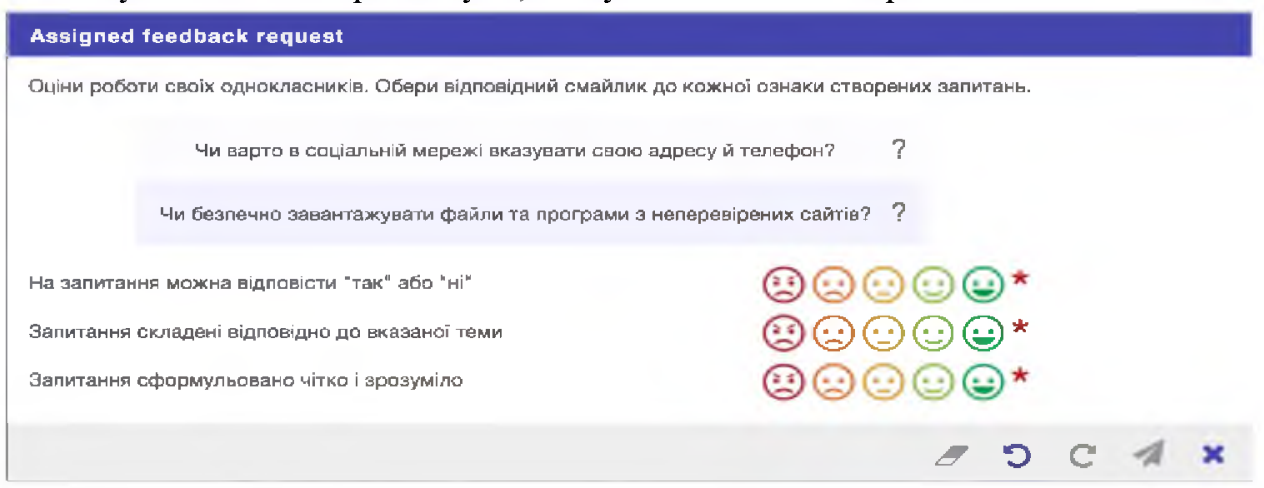

Рис. 5. Оцінювання за заданими критеріями в ILS

Для робіт творчого спрямування можна використовувати віртуальні дошки, зокрема padlet.com та блоги, наприклад, Blogger - один 3 сервісів Google, які можуть бути як одноосібними, так i 
спільними, створені кількома співавторами, що можуть публікувати дописи (див. рис. 6). В такому разі студенти мають змогу опублікувати свої роботи та за допомогою коментарів інших користувачів (див. рис. 7) здійснювати рефлексію.

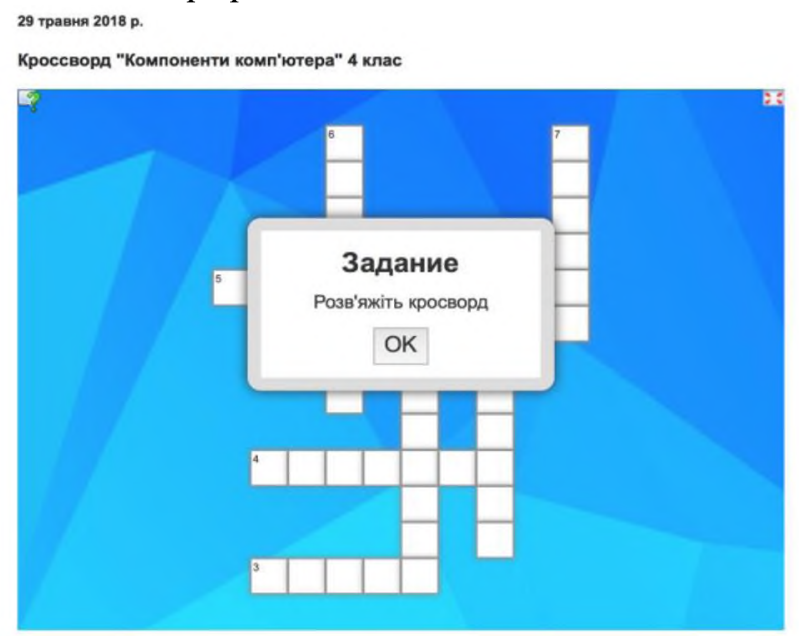

$\sqrt{ }$

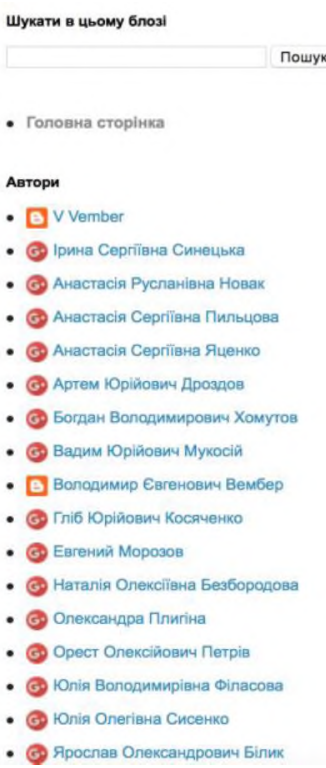

Рис. 6. Ведения спільного блогу

3 коментарі:

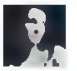

АнастасІя Cергївна Яценко 25 трав. 2018 р., 14:07:00

Завдання підходить для учнів 7-8 класу. Чудове завдання на перевірку Базових знань учнів, а також на їх закріплення.

Відповісти

- Відповіді

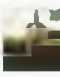

Богдан Володимирович Хомутов 25 трав. 2018 р., 14:08:00

Дякую:)

Bідповісти

Ярослав Олександрович БІлик 29 трав. 2018 р., 14:06:00

Прекрасно виконане завдання. Має багато картинок, котрі легко сприймаються. Особливої уваги заслуговує додаткове практичне завдання.

Відповісти

Рис.7. Коментування допису у блозі

Реалізувати пірінгове оцінювання можна також за допомогою додатків Google. Для відображення критеріїв оцінювання та надання можливості студентам виставити бали можна використати Google Таблиці, в такому разі обгрунтування оцінки може бути подано в коментарях (див. рис.8). Якщо в разі оцінювання окрім балу додається ще й описова складова, можна скористатись ресурсами Google Форми або Google Документи.

Оцініть роботи одногрупників, клітинки яких у рядку з вашим прізвищем внділені зепеним кольором (наприклап, Алlна Олегівна Антохове має оцінити роботи Єлизавети Руспланівни Веремей, Ірини Сергіїни Гребеник та Анастасії Василізни Кушнірук і т.д.). Оцінка мае бути загальна, як сума бапів за всіма вказаними критеріями від 1 до 7, максимапьна оцінка - 12 балів. Звертайте увагу на об'ективність оцін

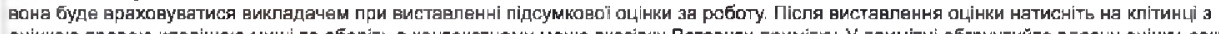
оцінкою правою клавішею миші та оберіть в контекстному меню вказівку Вставити примітқ. у принітці обгрунтуйте власну оцінку, зокрема якщо оцінка нв максимальна - вкажіть, за що знижено бали.

\begin{tabular}{|c|c|c|c|c|c|c|c|c|c|c|}
\hline 2 & & $\begin{array}{l}\text { Aniнa Олегівна } \\
\text { Aнtтохове }\end{array}$ & 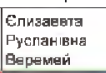 & \begin{tabular}{|l|} 
|рина Сергігїна \\
Гребеник
\end{tabular} & $\begin{array}{l}\text { Aнастасін } \\
\text { Ввсмлівна } \\
\text { Кучни рук }\end{array}$ & $\begin{array}{l}\text { Оксанз } \\
\text { вванівна } \\
\text { Пісаховсьска }\end{array}$ & \begin{tabular}{|l|l} 
Oксзна \\
Юрйвна Л=бах
\end{tabular} & \begin{tabular}{|l} 
Каринав \\
Петр вна \\
Полович
\end{tabular} & $\begin{array}{l}\text { Марина } \\
\text { олександрівна } \\
\text { Пропан }\end{array}$ & \begin{tabular}{|l|} 
Олвна \\
Эоподимирівна \\
Члій
\end{tabular} \\
\hline 3 & $\begin{array}{l}\text { Aniнa Oneriвна } \\
\text { Antroxcisa }\end{array}$ & & & 19 & 12 & \multirow{3}{*}{\multicolumn{2}{|c|}{ 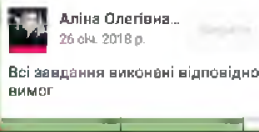 }} & & & \\
\hline 4 & $\begin{array}{l}\text { Eпизавета } \\
\text { Рүзананна Еврамей }\end{array}$ & & & 12 & 12 & & & & & \\
\hline 5 & $\begin{array}{l}\text { Ірина Сергі їна } \\
\text { Гребеник }\end{array}$ & & & & 12 & & & & & \\
\hline 5 & 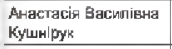 & & & & & 12 & 12 & 12 & & \\
\hline 7 & 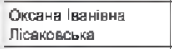 & & & & & & 12 & 12 & 12 & \\
\hline 8 & $\begin{array}{l}\text { Oисана Юрй̈на } \\
\text { MaБах }\end{array}$ & & & & & & & 12 & 12 & 12 \\
\hline 9 & $\begin{array}{l}\text { Карина Пөтрівна } \\
\text { Попович4 } \\
\end{array}$ & & & & & & & & 12 & 12 \\
\hline
\end{tabular}

Puc. 8. Google Таблицяя для пірінгового оцінювання 
Навчання в умовах «peer-to-peer» ставить перед педагогом нові завдання. Освітяни мають бути готовими якісно дібрати технології для реалізації пірінгової взаємодії. Студент, в свою чергу, має навчитись бути відповідальним за поданий ним контент, володіти навичками комунікації та співробітництва, критично мислити та вміло долати конфліктні ситуації.

Після вивчення будь якої навчальної дисципліни студент має чітко усвідомлювати, які саме навички та компетентності він здобув, і пірінгова взаємодія є одним із засобів, що надає можливість відслідкувати всі свої слабкі та сильні сторони, визначити прогалини в знаннях та здійснити рефлексію.

Дослідження, результати якого подані в статті, проведено в рамках проекту «Модернізація педагогічної вищої освіти з використання інноваційних інструментів викладання) (MoPED) програми ЄC Еразмус + КА2 - Розвиток потенціалу вищої освіти, № 586098-EPP-1-2017-1-UA-EPPKA2-CBHEJP. Цей проект фінансується за підтримки Європейської Комісії. Ця стаття відображає лише погляди авторів, і Свропейська Комісія не може нести відповідальність за будь-яке використання матеріалів, шо містяться в ній.

\section{Список використаних джерел:}

1. Morze Nataliia, Vember Viktoriia, Varchenko-Trotsenko Liliia (2017) Formative and peer assessment in high ereducation. IT tools. Good Practice of Effective Use in Education. Monograph, Sc. Editor: Eugenia Smyrnova-Trybulska, University of Silesia in Katowice, Katowice - Cieszyn, 2017. P.159180.

2. Peer 2 Peer University. URL: https://www.p2pu.org/en/ (дата звернення: 02.03.2019).

3. Melanie M. Nedder, Sharon A. Levine, Caroline Galligan, Kathleen Ryan Avery, Elizabeth EaganBengston, Karen M. Reilly. URL: http://ccn.aacniournals.org/content/37/l/el.full (дата звернення: 05.03.2019).

4. Golabz.eu. URL: https://www.golabz.eu/apps (дата звернення: 28.02.2019).

\section{References:}

1. Morze Nataliia, Vember Viktoriia, Varchenko-Trotsenko Liliia (2017) Formative and peer assessment in high ereducation. IT tools - Good Practice of Effective Use in Education. Monograph, Sc. Editor: Eugenia Smyrnova-Trybulska, University of Silesia in Katowice, Katowice - Cieszyn, 2017. P.159180 .

2. Peer 2 Peer University. URL: https://www.p2pu.org/en/ (data zvernennya: 02.03.2019).

3. Melanie M. Nedder, Sharon A. Levine, Caroline Galligan, Kathleen Ryan Avery, Elizabeth EaganBengston, Karen M. Reilly. URL: http://ccn.aacnjournals.org/content/37/1/el.full (data zvernennya: 05.03.2019).

4. Golabz.eu. URL: https://www.golabz.eu/apps (data zvernennya: 28.02.2019).

\section{Use of cloud services for peer to peer interaction in educational process}

\section{V.P. Vember, D.L. Nastas}

Abstract. The article addresses the problem of modernization of education, including introducing features peer to peer interaction in the educational process of educational institutions. Examples of existing peer interaction systems abroad and in Ukraine are considered. The features of peer assessment and tips for developing criteria for evaluation are provided. The cloud services that can be used to implement peer-topeer interaction and peer assessment, including some resources in LMS Moodle, inquiry learning spaces, Google applications, such as Google Tables, Google Forms, Google Docs, blogs and virtual boards are considered, and features of their use have been investigated.

Keywords: peer-to-peer, peer to peer interaction, peer assessment, cloud services.

DOI 10.31392/NPU-nc.series 2.2019.21(28).21

УДК 001.92:51

О.Д. Нестерова

старший викладач

Національний педагогічний університет імені М.П. Драгоманова

\section{ДЕЯКІ ПИТАННЯ ТА ПРИКЛАДИ ПОПУЛЯРИЗАЦІЇ МАТЕМАТИКИ}

Анотація. Метою статті $€$ постановка актуального питання підвищення рівня математичної грамотності, ерудованості, елементів загальної культури членів суспільства, подолання негативного іміджу математики шляхом популяризації науки. В статті розглядаються причини низького рівня 